\title{
Limited nuclear programme favoured
}

IN the referendum on nuclear power held on 23 March, $58 \%$ of Swedes voted for the completion of the present 12 reactor programme, but only $18.7 \%$ gave their approval to anything beyond that.

The referendum was a political exercise from start to finish (see Nature 13 March 1980 , pages $117-8$ ), and it came as no surprise that the combined forces of the two pro-nuclear options outweighed the support mustered by the single anti-nuclear one. Nevertheless, the success of the antinuclear movement should not be underestimated. Against the opposition of three of the four major parties, the trades union movement and industry, it managed - with far less money but far more personal engagement than its rivals - to gather nearly $40 \%$ of the voters to its side. The members of the anti-nuclear campaign, led by Lennart Daléus, are unanimous that their fight will go on, although the form of their future organization has yet to be decided.

On the pro-nuclear side, the softer option which recommended carrying out the planned 12-reactor programme but not building any more turned out to be marginally the most popular option of all, polling $39.3 \%$. The more enthusiastically pro-nuclear option polled $18.7 \%$. The fact that nearly $78 \%$ of the voters supported options which, with some credibility, demanded phasing out nuclear power, suggests that the population at large accepts nuclear power for a limited period while renewable energy sources are further developed, but by no means wholeheartedly embraces it as the energy system of the future.

Even if this is a reasonable interpretation of the attitude of most people, it remains to be seen whether the politicians will act on it. While they will be under intense pressure to increase funding for renewable energy sources, their immediate tasks will be to bring more reactors on-line. It seems certain that the Ringhals-3 and Forsmark-1 reactors will be quickly loaded: permission to load them has already been given but the actual loading was held up pending the referendum result. The State Power Board has also sought permission to load the Forsmark- 2 and Ringhals- 4 reactors, but as the reprocessing contract presently in force between the Swedish nuclear fuel supply company (SKBF) and the French firm Cogema does not provide for sufficient capacity to reprocess all the spent fuel from these two reactors, permission to run them will initially be limited to that time which will not produce more waste than the present contract could handle.

If, as the board hopes, Forsmark-2 were loaded in the spring of 1981, and Ringhals-4 in the spring of 1982, the present agreement would take care of wastes produced from them both until the end of 1985 . SKBF is currently trying to persuade Cogema to reprocess an extra 50 tons of spent fuel, which would cover the reactors until the end of 1986 . Construction work will also go ahead on the depot for intermediary storage of spent fuel near the Oskarshamn reactors. According to a spokesman at the State Power Board, it seems unlikely that new reprocessing agreements will be concluded in the 1980s, so this depot will have to take care of spent fuel until new reprocessing agreements could be made in the longer term or until a decision were taken to store the waste directly, without reprocessing it.

Anti-nuclear Centre Party Prime Minister Torbjörn Fälldin has no intention of resigning, in spite of the fact that he had

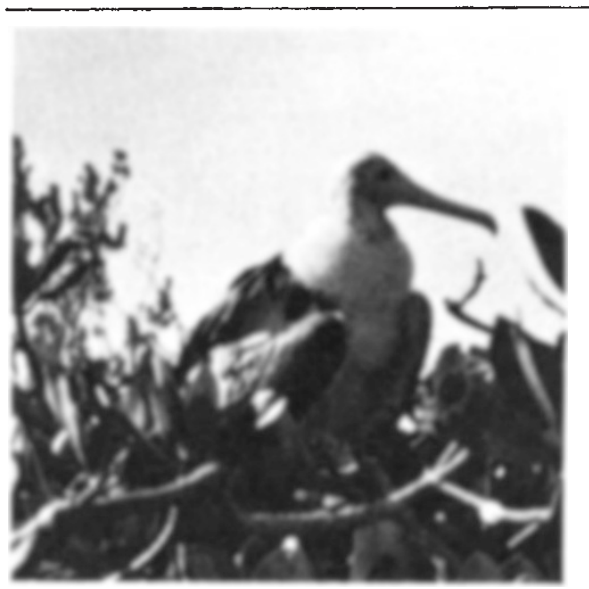

Aldabra has the largest breeding colony of frigate birds (Fregata) in the western Indian Ocean.

\section{Environment}

\section{Aldabra faces problems}

AlDABRA, the atoll in the Indian Ocean that narrowly escaped becoming an air staging post 13 years ago, once more faces an uncertain future. On 31 March wardenship of the atoll and its ecological treasures passed from the Royal Society, which has maintained a programme of research and conservation since the first alarm, to the Seychelles Islands Foundation. This new public trust has members representing the Seychelles government, the Royal Society, the Smithsonian Institution and international organizations well attuned to the scientific value of an island virtually unscathed by human interference, but its task will not be easy. The foundation will need $\$ 120,000$ a year to maintain its research station and scientific programme.

The inhospitability of Aldabra has preserved it from most of the exploitation staked all his prestige and moral strength behind the anti-nuclear campaign. His reaction to the result was to say that the people's desire for a maximum of 12 reactors must be respected. This has been seized on by his opponents as an opening shot in a campaign to do away with the twelfth reactor, Oskarshamn-3. The present government is a coalition of the Conservative, Liberal and Centre parties, and such a campaign would be carried on for purely political motives. It would be supported by some sections of the Liberal and Social Democratic parties, but staunchly opposed by the Conservatives' leader, Goesta Bohman, who backed the referendum's most pro-nuclear option. The coalition is undoubtedly in for some tough in-fighting.

Wendy Barnaby

suffered by other oceanic islands. The goats, cats, rats and mice introduced after 1880 , when a small settlement began on the west island, have not wrought ecological havoc on the other three islands of the atoll. And so when the UK government announced in 1966 its intention to set up a military airfield on the atoll, ecologists realized that they were about to lose a unique ecosystem, where biogeographical and evolutionary theories could be tested.

The Royal Society became the focus for international concern, and mounted an expedition in 1967 to make an inventory of the terrestrial and marine features of the atoll before development began. But in the meantime the plans for the airfield were abandoned, and the society established a more permanent presence. A small research station was built, and in 1971 the society acquired the lease of the atoll, making possible a more comprehensive programme of research, which continued when Aldabra passed into the care of the Republic of Seychelles in 1976.

Since then almost 100 visitors have studied the geology, flora and fauna of Aldabra, making it one of the best known of all oceanic islands and coral atolls. Among the most spectacular of the fauna is the unique colony of about 150,000 giant tortoises, Aldabrachelys gigantes (a subspecies of Geochelone).

The future of this work is uncertain because the Seychelles Islands Foundation must rely on its own financial resources. In November 1979 it launched an appeal for at least a million dollars to provide an endowment, the income from which could be used to conserve Aldabra in perpetuity. So far more than $\$ 300,000$ has been raised, but that will not support the scientific presence much beyond the end of 1980 .

Mary Lindley

The World Wildife Fund, 29 Greville Street, London ECI 8AX, is a focus for the appeal in the $U K$. 